\title{
Sucrose preload reduces snacking after mild mental stress in healthy participants as a function of 5- hydroxytryptamine transporter gene promoter polymorphism
}

Citation for published version (APA):

Markus, C. R., Jonkman, L. M., Capello, A., Leinders, S., \& Husch, F. (2015). Sucrose preload reduces snacking after mild mental stress in healthy participants as a function of 5-hydroxytryptamine transporter gene promoter polymorphism. Stress-the International Journal on the Biology of Stress, 18(2), 149-159. https://doi.org/10.3109/10253890.2014.990880

Document status and date:

Published: 01/03/2015

DOI:

10.3109/10253890.2014.990880

Document Version:

Publisher's PDF, also known as Version of record

\section{Document license:}

Taverne

\section{Please check the document version of this publication:}

- A submitted manuscript is the version of the article upon submission and before peer-review. There can be important differences between the submitted version and the official published version of record. People interested in the research are advised to contact the author for the final version of the publication, or visit the $\mathrm{DOI}$ to the publisher's website.

- The final author version and the galley proof are versions of the publication after peer review.

- The final published version features the final layout of the paper including the volume, issue and page numbers.

Link to publication

\footnotetext{
General rights rights.

- You may freely distribute the URL identifying the publication in the public portal. please follow below link for the End User Agreement:

www.umlib.nl/taverne-license

Take down policy

If you believe that this document breaches copyright please contact us at:

repository@maastrichtuniversity.nl

providing details and we will investigate your claim.
}

Copyright and moral rights for the publications made accessible in the public portal are retained by the authors and/or other copyright owners and it is a condition of accessing publications that users recognise and abide by the legal requirements associated with these

- Users may download and print one copy of any publication from the public portal for the purpose of private study or research.

- You may not further distribute the material or use it for any profit-making activity or commercial gain

If the publication is distributed under the terms of Article 25fa of the Dutch Copyright Act, indicated by the "Taverne" license above, 


\title{
Sucrose preload reduces snacking after mild mental stress in healthy participants as a function of 5-hydroxytryptamine transporter gene promoter polymorphism
}

\author{
C. Rob Markus, Lisa M. Jonkman, Aimee Capello, Sacha Leinders \& Fabian \\ Hüsch
}

To cite this article: C. Rob Markus, Lisa M. Jonkman, Aimee Capello, Sacha Leinders \& Fabian Hüsch (2015) Sucrose preload reduces snacking after mild mental stress in healthy participants as a function of 5-hydroxytryptamine transporter gene promoter polymorphism, Stress, 18:2, 149-159, DOI: $10.3109 / 10253890.2014 .990880$

To link to this article: https://doi.org/10.3109/10253890.2014.990880

\section{曲 Published online: 29 Dec 2014.}

[3. Submit your article to this journal ๒

Llll Article views: 188

Q View related articles $\widetilde{ }$

View Crossmark data $\asymp$

Citing articles: 2 View citing articles 


\title{
Sucrose preload reduces snacking after mild mental stress in healthy participants as a function of 5-hydroxytryptamine transporter gene promoter polymorphism
}

\author{
C. Rob Markus ${ }^{1}$, Lisa M. Jonkman ${ }^{2}$, Aimee Capello ${ }^{1}$, Sacha Leinders ${ }^{1}$, and Fabian Hüsch ${ }^{1}$ \\ ${ }^{1}$ Department of Neuropsychology \& Psychopharmacology, Faculty of Psychology and Neuroscience and ${ }^{2}$ Section of Developmental Psychology, \\ Department of Cognitive Neurosciences, Faculty of Psychology and Neuroscience, University Maastricht, Maastricht, The Netherlands
}

\begin{abstract}
Brain serotonin (5-hydroxytryptamine, 5-HT) dysfunction is considered to promote food intake and eating-related disturbances, especially under stress or negative mood. Vulnerability for 5-HT disturbances is considered to be genetically determined, including a short (S) allele polymorphism in the serotonin transporter gene (5-HTTLPR) that is associated with lower serotonin function. Since 5-HT function may be slightly increased by carbohydrate consumption, S-allele 5-HTTLPR carriers in particular may benefit from a sugar-preload due to their enhanced 5-HT vulnerability. The aim of the current study was to investigate whether a sugarcontaining preload may reduce appetite and energy intake after exposure to stress to induce negative mood, depending on genetic 5-HT vulnerability. From a population of 771 healthy young male and female genotyped college students $31 \mathrm{~S} / \mathrm{S}$ carriers (8 males, 23 females) and 26 long allele (L/L) carriers (9 males, 17 females) (mean \pm S.D. $22 \pm 1.6$ years; body mass index, BMI, $18-33 \mathrm{~kg} / \mathrm{m}^{2}$ ) were monitored for changes in appetite and snacking behavior after stress exposure. Results revealed an increased energy intake after mild mental stress (negative mood) mainly for high-fat sweet foods, which was significantly greater in S/S carriers, and only in these genotypes this intake was significantly reduced by a sucrose-containing preload. Although alternative explanations are possible, it is suggested that $\mathrm{S} / \mathrm{S}$ participants may have enhanced brain (hypothalamic) 5-HT responsiveness to food that makes them more susceptible to the beneficial satiation effects of a sucrose-preload as well as to the negative effects of mild mental stress on weight gain.
\end{abstract}

Keywords

5-HTTLPR, mild stress, mood, snacking, sucrose, serotonin

\section{History}

Received 11 March 2014

Revised 18 November 2014

Accepted 19 November 2014

Published online 18 December 2014

\section{Introduction}

The frequencies of overweight and obesity have resulted in an alarmingly increasing epidemic worldwide, and these conditions are considered to be two of today's most severe threats to human health. Among the various risk factors involved in susceptibility to weight gain, stress is the most commonly suggested. Although the typical eating-related response to physical stress is a loss of appetite, people may increase their food intake when feeling stressed or depressed (Epel et al., 2001; Greeno \& Wing, 1994; Heatherton et al., 1991; Mitchell \& Epstein, 1996; Rutters et al., 2009) and this is particularly found for high-fat high sugar snack foods (Rutters et al., 2009; Oliver et al., 2000; Zellner et al., 2006). Consequently, the vulnerability to eat in response to negative mood ("emotional eating"), increases the risk of obesity and

Correspondence: Dr. C. R. Markus, Department of Neuropsychology \& Psychopharmacology, Faculty of Psychology and Neuroscience, University Maastricht, Universiteitssingel 40, 6229 ER Maastricht, The Netherlands. Tel: 043-3882474. Fax: 043-3884196. E-mail: r.markus @ maastrichtuniversity.nl eating disorders (Bennett \& Cooper, 1999; Racine et al., 2009; Van Strien et al., 2005).

Emotional eating may be partly attributed to reduced functionality of the brain serotonergic (5-HTergic) system. Reduced brain 5-HT function has been associated with reduced stress resilience and, hence, with a greater risk of experiencing negative mood or depression symptoms (Gotlib et al., 2008; Jans et al., 2007; Markus, 2008) and with increased snacking for high-fat sweet foods particularly (Brewerton, 1995; Simansky, 1996). In addition, 5-HT function is directly involved in the regulation of eating behavior (Lucki, 1998). For instance, reduced brain 5-HT levels are associated with negative mood and with an increased urge for binge eating (Bruce et al., 2009), whereas increasing brain 5-HT through the use of 5-HT releasing agents is used as a pharmacological treatment strategy for obesity (Hoy, 2013). In addition, pharmacological studies have revealed that 5-HT function in hypothalamic food intake-control areas is involved in the selective intake of fatty, sweet or savory foods and is therefore involved in controlling body weight (Leibowitz \& Alexander, 1998; Leibowitz et al., 1989; Stallone \& Nicolaidis, 1989; Simansky, 1996). 
Consequently, there is increasing evidence that reduced brain 5-HT function plays a key role in the neurobiology of eating disorders (Kaye, 2008).

Considering the role of 5-HT in mood and stress resilience, genetic variation in 5-HT function has been found to be a vulnerability factor for the negative effects of stress exposure. In this respect, the 5-HT transporter gene (SLC6A4) is the most likely candidate because it mediates pre-synaptic reuptake of 5-HT and thus terminates 5-HTergic neurotransmission. A common functional polymorphism in the promoter region of the 5-HT transporter gene (5-HTTLPR), which includes one short (S) allele and one long (L) allele, influences 5-HT function. The S-allele variant is associated with lower transcriptional efficiency of 5-HTT than the L-allele variant (Heils et al., 1996) and is associated with lower 5-HTT mRNA expression, less 5-HT binding and reuptake, and therefore with 5-HT dysfunction and vulnerability (Lesch et al., 1996). Accordingly, the S-allele 5HTTLPR has been associated with increased affective symptoms in response to life events (Caspi et al., 2003; Karg et al., 2011; Uher, 2008) and with increased stress responsiveness to laboratory stressors (Alexander et al., 2009; Gotlib et al., 2008; Markus \& De Raedt, 2011; Way \& Taylor, 2010). Thus, assuming that stress may disturb energy intake, particularly by increasing preferences for high-fat sweet foods, and that 5HTTLPR mediates stress resilience, it is hypothesized that the effect of stress on food preferences depends on the 5-HT transporter gene. Indirect support is based on a few association studies, which either show direct associations between 5-HTTLPR and weight gain (Calati et al., 2010; Erritzoe et al., 2010; Sookoian et al., 2007a, 2008) or an inter-relationship between 5-HTTLPR, past adverse events and problematic eating behaviors (Akkerman et al., 2012; Stoltenberg et al., 2012; Van Strien et al., 2010). However, the interaction between 5-HTTLPR and affective stress responses and its effect on eating-related behavior have not yet been experimentally investigated.

Brain 5-HT vulnerability or susceptibility for serotonin disturbances and/or manipulations, appears to mediate the influence of stress on energy intake; brain 5-HT levels in turn may be increased by carbohydrate-rich, protein-poor food intake. Consequently, carbohydrate intake has sometimes been found, yet not consistently, to improve mood (Benton, 2002) and/or affective stress adaptation in vulnerable subjects (Markus, 2008b). Hence, carbohydrate intake (depending on its proportional ratio with protein) may increase the plasma concentration of the 5-HT precursor amino acid tryptophan (TRP) relative to the combined concentration of the other large neutral amino acids (LNAAs), giving TRP a competitive advantage for access to the brain (Fernstrom \& Wurtman, 1971; Wurtman et al., 2003). A carbohydrate-induced increase in the plasma TRP/LNAA ratio is caused by a glucose increase that triggers insulin secretion and facilitates the uptake of the LNAAs, but not TRP, into the skeletal muscles (Fernstrom \& Wurtman, 1971; Wurtman et al., 2003). These dietary effects of carbohydrates on the TRP/ LNAA ratio have been often reported (Markus, 2008; Markus et al., 1998, 1999; Wurtman et al., 2003).

Based on the relationships between stress and eating behavior and between 5-HT, carbohydrate intake and stress resilience, it is suggested that the consumption of a sucrose-containing preload may reduce the negative effects of stress exposure on mood and eating behavior as a function of genetic 5-HT vulnerability. The current study investigated this relationship, testing the hypothesis that individuals with 5-HTTLPR S/S genotypes will show greater stress responsiveness and hence greater craving for high-fat sweet foods compared to high-fat savory foods. Furthermore, due to the assumed 5-HT vulnerability in S-allele genotype carriers and the previously identified effects of sugar challenge on mood and stress resilience, a sucrose-containing preload was expected to reduce the negative effect of stress on mood and subsequent increase in high-fat sweet food intake compared to high-fat savory food craving and intake, particularly in S/S allele genotypes.

\section{Methods}

\section{Participants}

From a recently obtained DNA 5-HTTLPR database of $N=771$ undergraduate students at Maastricht University $(21 \% \mathrm{~S} / \mathrm{S}, 51 \% \mathrm{~S} / \mathrm{L}$ and $28 \% \mathrm{~L} / \mathrm{L})$ homozygous S-allele carriers (carrying the $\mathrm{S} / \mathrm{S}, \mathrm{S} / \mathrm{Lg}$ or $\mathrm{Lg} / \mathrm{Lg}$ allele) and L-allele carriers (carrying the La/La allele) were invited to participate. Only homozygous S or L-allele carriers were included in order to maximize the potential differences between the genotypes (Caspi et al., 2010; Sookoian et al., 2008; Zalsman et al., 2006). All these participants completed a questionnaire screening package concerning general information (health, personal or family history of medical or psychiatric complaints, smoking and drinking habits, caffeine consumption, weight and height, use of psychoactive drugs) and completed several questionnaires concerning relevant symptoms, psychopathology and eating styles. These $\mathrm{S} / \mathrm{S}$ and $\mathrm{L} / \mathrm{L}$ allele carriers were encouraged to participate if: (1) they were able to join near springtime (April-May 2012), and (2) they reported the absence of chronic or current physical or psychiatric illness; family history of psychiatric illness; medication use; metabolic, hormonal or intestinal diseases; irregular diets or deviant eating habits; excessive use of alcohol ( $>2$ units a day), coffee ( $>10$ units a day), cigarettes or other drugs; aversion for certain foods; and pregnancy. Following this selection, $31 \mathrm{~S} / \mathrm{S}$ carriers (8 males, 23 females) and $26 \mathrm{~L} / \mathrm{L}$ carriers ( 9 males, 17 females) were included in the study. Participants were between 20 and 27 years of age (mean age \pm S.D. $=22 \pm 1.6$ years) with a body mass index between 18 and 33 (mean BMI $=22.4 \pm 3.0$ S.D.). The study was followed in accordance with the Helsinki Declaration of 1975 as revised in 1983 and participants gave their written informed consent and were paid for participation.

\section{Design and procedure}

In order to prevent "learned satiation" as often found in dietary within-subjects designs (Brunstrom, 2007; Gibson et al., 2006), the current study was conducted in accordance with a double-blind placebo-controlled between-subjects design. Participants visited the laboratory in the morning between 09:00 and 11:00 $\mathrm{h}$ to monitor their mood, appetite and liking for food before and after acute stress exposure as well as their actual food intake after stress completion following a sucrose (CHO) containing or placebo (PLC) 
$\mathrm{N}=771$ DNA 5-HTTLPR

$(21 \% \mathrm{~S} / \mathrm{S}, 51 \% \mathrm{~S} / \mathrm{L}, 28 \% \mathrm{~L} / \mathrm{L})$

$158 \mathrm{~S} / \mathrm{S}, 217 \mathrm{~L} / \mathrm{L}$
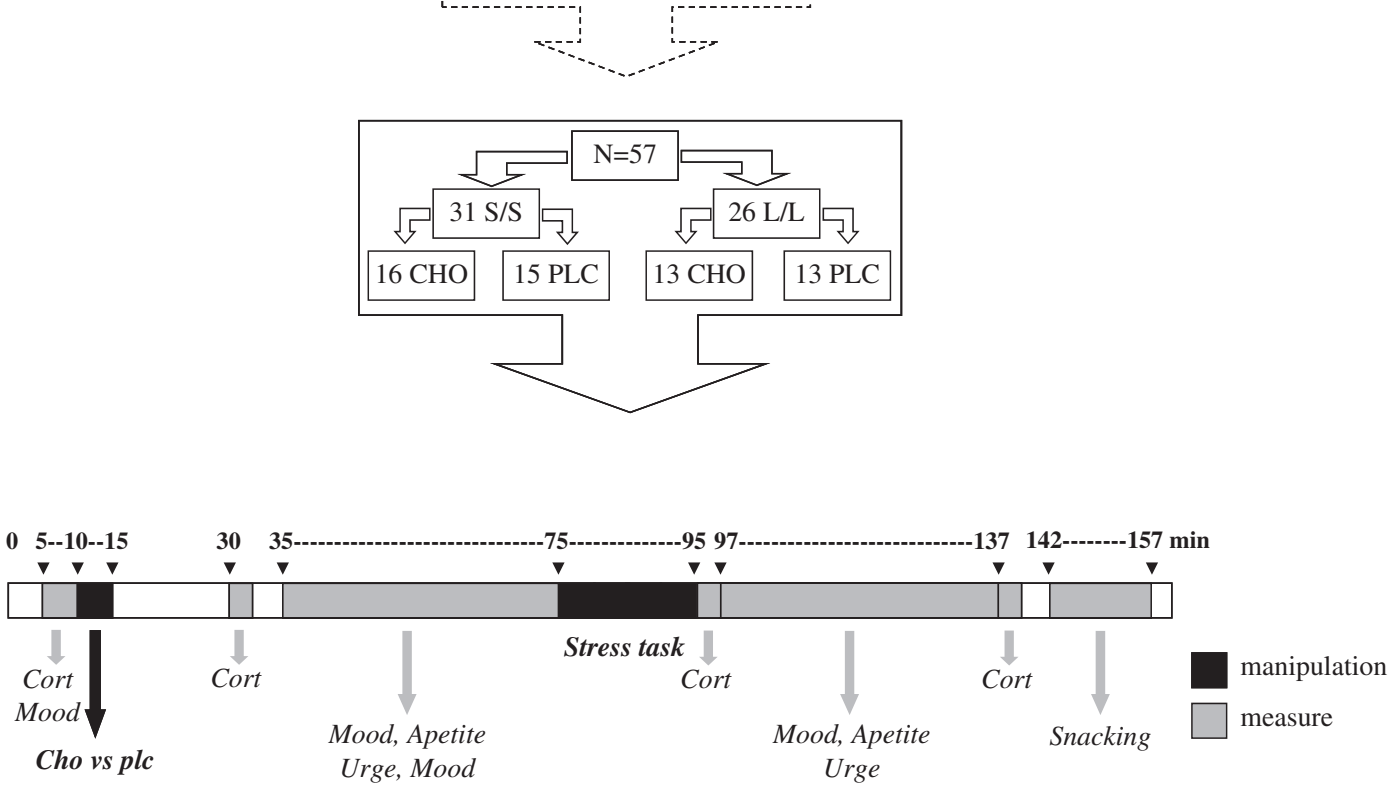

Figure 1. Design of the experiment. From a large DNA 5-HTTLPR (5-HT Transporter Linked Polymorphic Region) database S/S $(N=31,8$ males) and $\mathrm{L} / \mathrm{L}(N=26,9$ males) genotypes were selected and divided into a sucrose-containing (CHO) or placebo (PLC) preload condition. During the acute laboratory stress exposure session, subjects were monitored for changes in salivary cortisol concentration (Cort), mood, appetite and attention for food cues before and after stress, and for snacking after stress, following intake of a sucrose (CHO) containing or placebo (PLC) preload.

preload. Participants were instructed to refrain from alcohol for at least 36 hours and to fast 12 hours before onset of the test sessions; only water or caffeine-free tea without sugar was permitted. Participants were told that a compliance check would be included during their first visit; by way of a baseline salivary sample (which was actually not used for this purpose). Figure 1 shows a schematic diagram and time table of the experimental procedure.

On each laboratory test day, 5-8 participants arrived at the laboratory waiting room at 09:00 h. Five minutes after arrival and a little rest, a first saliva sample and mood measurement were taken, immediately followed by supervised consumption of a CHO or PLC preload. Then, participants filled in a general information form (checking compliance and complaints) and then were allowed to rest and to read magazines for $30 \mathrm{~min}$. Next, $25 \mathrm{~min}$ after CHO or PLC consumption, a second saliva sample was taken after which all participants were brought into their own separated test compartment (as part of a large experimental room) to conduct a test battery including a mental arithmetic stress task preceded and followed by tests measuring mood, appetite and liking for foods (see detailed description below). Directly after this test battery (approximately 11:30 h), participants were told that the main experiment was over and that they only needed to acclimatize for $15 \mathrm{~min}$ (while filling in some final questionnaires) still in their own isolated test compartment. During this acclimatization period, they had free access to preweighed portions of snack foods and were allowed to eat as much as they wished before leaving. All parts of the procedure were conducted under (indirect-) guidance by a test assistant blind to the test or experimental conditions (to assure complete compliance to test adherence to dietary restriction regulations by participants). After completion, participants went home and were instructed not to share details of the tests to others until they receive a debriefing by mail.

\section{Preload}

Participants were administered a $400 \mathrm{ml}$ blackcurrant juice drink that differed in energy content (CHO or PLC; generously supplied by United Soft Drinks BV, Utrecht; The Netherlands). The experimental sucrose (CHO) condition contained a sucrose-containing $400 \mathrm{ml}$ juice drink $(178 \mathrm{kcal})$ whereas the placebo (PLC) condition contained a zero-energy artificially sweetened (aspartame, saccharine) $400 \mathrm{ml}$ juice drink $(3.6 \mathrm{kcal})$. Both drinks were manufactured to reach equal taste, appearance and pleasantness. To ensure doubleblinding; the drinks were daily (re)labeled (D1 and D2, respectively for $\mathrm{CHO}$ and PLC in random order) and allocated to the participants by their identification number by a staff member not directly involved in daily measurements or in contact with the participants. In addition, the labeled drinks were prepared by two research assistants blind to experimental (dietary, genotype) conditions by mixing $70 \mathrm{ml}$ of the labeled PLC or CHO syrup and $330 \mathrm{ml}$ of tap water. Each test day, one of the research assistants supervised the preload intake to make sure that the drinks were consumed within 5 min (see Table 1 for nutrient constitution).

\section{Stress manipulation}

The Markus-Peters arithmetic stress-task (MPA) (Markus et al., 1998) was used as an uncontrollable stress situation. Participants were placed in front of a computer screen and 
Table 1. Total nutrient composition (grams) of the sucrose (CHO) containing and placebo (PLC) preload.

\begin{tabular}{lcc}
\hline & $\begin{array}{c}\text { CHO-preload } \\
(400 \mathrm{ml})\end{array}$ & $\begin{array}{c}\text { PLC-preload } \\
(400 \mathrm{ml})\end{array}$ \\
\hline Sugar (sucrose) & 43.7 & - \\
Sodium saccharin & - & 0.006 \\
Ascorbic acid & 0.007 & 0.007 \\
Natrium cyclamate & - & 0.025 \\
Potassium sorbate & 0.028 & 0.028 \\
Aspartame & - & 0.046 \\
Acesulfame K & - & 0.046 \\
Raspberry flavor & 0.035 & 0.084 \\
Elderberry concentrate & 0.28 & 0.28 \\
Lemon acid & 0.63 & 0.63 \\
Energy (kcal/kJ) & $178 / 745$ & $3.6 / 15$ \\
\hline
\end{tabular}

camera. Then they were exposed to 20 successive 1-min trials during which they had to solve a specific number of multiple choice mental arithmetic problems (the criterion) under timeconstraints, while at the same time continuous $80 \mathrm{~dB}$ industrial noise was presented to them through headphones. They were led to believe that the presence or absence of the noise depended on their performance: if they failed the criterion, noise would be present during the next trial; if they met the criterion, noise would be absent. In addition, they were told that their performance and facial expressions were recorded, and that the best and worst performing participant would be announced after completion. In fact, the criterion was manipulated so that all participants continued to fail on each trial. The criterion was always set at one sum above what the participants could manage as calculated from the average time per sum needed on previous trials. Moreover, recordings and measurements of performance were not made; after completion participants were told that this did not work due to instrumental problems.

\section{Measurements}

Mood

Changes in mood were measured using the Dutch shortened version of the Profile of Mood States (POMS) questionnaire (Wald \& Mellenbergh, 1990), offered as a 100-unit computerized visual-analogue scale ranging from "not at all" to "extremely". The POMS comprises five different subscales for mood; ranging from Anger, Tension, Depression and Fatigue that refer to a negative mood state, to Vigor concerning a positive mood.

\section{Appetite}

Changes in subjective sensations of appetite were measured using a computerized $100-\mathrm{mm}$ visual analogue scale procedure to assess: (1) appetite to start a meal, (2) appetite for a sweet snack, (3) appetite for a savory snack, (4) hunger or (5) satiety (fullness). Responses to 1, 4 and 5 were combined into a general score for general appetite to start a meal $(1+4$ minus 5), whereas the scores on 2 and 3 were separately analyzed to indicate appetite for a sweet or savory snack.

\section{Food liking computer test}

An adapted version of the computerized food hedonic test procedure (Finlayson et al., 2007) was used to assess the
Table 2. Constitution and energy content (per 100g) of the snacks offered as four different food categories.

\begin{tabular}{lcccc}
\hline & $\begin{array}{c}\text { Carbohydrates } \\
(\mathrm{g})\end{array}$ & $\begin{array}{c}\text { Protein } \\
(\mathrm{g})\end{array}$ & $\begin{array}{c}\text { Fat } \\
(\mathrm{g})\end{array}$ & $\begin{array}{c}\text { Energy } \\
(\mathrm{kcal})\end{array}$ \\
\hline HFSW & & & & \\
$\quad$ Mini syrop wafles & 70 & 4 & 19 & 473 \\
$\quad$ M\&Ms (choco peanuts) & 70 & 5 & 21 & $4 \mathrm{~S} 7$ \\
HFSA & & & & \\
$\quad$ Peanuts & 14 & 25 & 51 & 626 \\
$\quad$ Crisps & 52 & 6 & 33 & 542 \\
LFSW & & & & \\
$\quad$ Raisins & 76 & 3 & 1 & 326 \\
$\quad$ English liquorice & 82 & 4 & 5 & 394 \\
LFSA & & & & \\
$\quad$ Salted sticks & 70 & 12 & 5 & 382 \\
$\quad$ Rice crackers & 82 & 7 & 2 & 383 \\
$\quad$ cheese flavour) & & & & \\
\hline
\end{tabular}

HFSW, High-fat sweet; HFSA, high-fat savory; LFSW, low-fat sweet; LFSA, low-fat savory.

rewarding value, i.e. liking, for photographic images of different foods. Sixteen photographic food stimuli were presented on a computer screen. The foods were arranged into separate categories of sweet (SW), savory (SA), high-fat (HF) and low-fat (LF) food items and combined to form highfat sweet (HFSW), low-fat sweet (LFSW), high-fat savory (HFSA) and low-fat savory (LFSA) categories. Each food picture was presented one at a time and rated according to a 100-unit VAS scale combined with the statement "How pleasant would it be to taste this food right now?', Mean ratings for each of the four food categories HFSW, HFSA, LFSW and LFSA were calculated.

\section{Snacking}

To measure actual snacking, participants were separately presented (in their own separate test compartment) with four food trays during a $15 \mathrm{~min}$ after-test acclimatization period. The food trays contained pre-selected and weighed portions of the experimental foods high-fat sweet (HFSW) and high-fat savory (HFSA), as well as low-fat sweet (LFSW) and low-fat savory (LFSA) foods. Directly after completion (after leaving), the food containers were weighed to determine the total amount of food intake per category. See table 2 for detailed information of the food constituents.

\section{Biochemical analysis}

\section{Genotyping}

Buccal cell samples for measuring tri-allelic variants of the 5-HTT-linked polymorphic region (5-HTTLPR) of the original database $(N=771)$ were obtained using sterile swabs (Omni Swabs, Whatman's Hertogenbosch, The Netherlands). Genomic DNA was isolated from buccal swabs using QIamp DNA Mini Kits from Qiagen (Westburg, Leusden, the Netherlands) for determination of the 5-HTTLPR genotype. Genotyping was performed using the polymerase chain reaction (PCR) protocol according to Glatz et al. (2003). In compliance with previous work (Markus \& De Raedt, 2011; Markus \& Firk, 2009; Neumeister et al., 2006; Walderhaug et al., 2007); tri-allelic variants were reclassified into a 
Table 3. Demographic and clinical characteristics (mean \pm SD) for the 5-HTTLPR genotype participants.

\begin{tabular}{|c|c|c|c|c|}
\hline & \multicolumn{2}{|c|}{ Women } & \multicolumn{2}{|c|}{ Men } \\
\hline & $\mathrm{S}^{\prime} / \mathrm{S}^{\prime}(S / S, S / L g, L g / L g)$ & $\mathrm{L}^{\prime} 7 \mathrm{~L}^{\prime}(\mathrm{La} / \mathrm{La})$ & $\mathrm{S}^{\prime} / \mathrm{S}^{\prime}(S / S, S / L g, L g / L g)$ & $\mathrm{L}^{\prime} / \mathrm{L}^{\prime}(\mathrm{La} / \mathrm{La})$ \\
\hline & 23 & 17 & 8 & 9 \\
\hline Age & $22.3 \pm 1.6$ & $22 \pm 1.5$ & $21.9 \pm 1.3$ & $22.2 \pm 1.9$ \\
\hline BMI & $23 \pm 3.5$ & $22 \pm 3.2$ & $22 \pm 1.8$ & $22.2 \pm 1.8$ \\
\hline BDI & $4.5 \pm 3.5$ & $3.4 \pm 3.5$ & $4.9 \pm 3.5$ & $2.3 \pm 2.7$ \\
\hline SKS-S & $2.2 \pm 2$ & $2.4 \pm 2.5$ & $3.1 \pm 2.8$ & $3.1 \pm 1.4$ \\
\hline TFEQ & $84.2 \pm 7.8$ & $80.3 \pm 11.5$ & $72.4 \pm 8.6$ & $77.6 \pm 7$ \\
\hline Disinhibition & $24 \pm 3.6$ & $22.9 \pm 4.9$ & $19.9 \pm 3.7$ & $23.1 \pm 4.5$ \\
\hline Hunger & $25 \pm 4$ & $25.5 \pm 4$ & $25.5 \pm 4.9$ & $27.1 \pm 3.7$ \\
\hline Restrain & $34.7 \pm 7.8$ & $32 \pm 7.8$ & $27 \pm 5$ & $27.3 \pm 6.7$ \\
\hline \multicolumn{5}{|l|}{ Snacking (PLC) } \\
\hline HFSW & $51.5 \pm 24.9$ & $39.8 \pm 46.1$ & $87.3 \pm 44.8$ & $43.7 \pm 27.8$ \\
\hline LFSW & $14 \pm 20$ & $12.6 \pm 14.1$ & $11.8 \pm 10$ & $2.7 \pm 4.6$ \\
\hline HFSA & $14.3 \pm 18.3$ & $21.6 \pm 19.4$ & $25.5 \pm 17.7$ & $39.8 \pm 40.2$ \\
\hline LFSA & $9.7 \pm 12.6$ & $13 \pm 15.2$ & $5.5 \pm 9.7$ & $12.7 \pm 18.7$ \\
\hline \multicolumn{5}{|l|}{ Snacking $(\mathrm{CHO})$} \\
\hline HFSW & $18 \pm 26.6$ & $48-3 \pm 41.3$ & $44.5 \pm 32.3$ & $46 \pm 12$ \\
\hline LFSW & $6.5 \pm 10.9$ & $12.5 \pm 20$ & $18 \pm 16.8$ & $5.3 \pm 6.8$ \\
\hline HFSA & $7.7 \pm 11$ & $17 \pm 17.4$ & $50.8 \pm 25.3$ & $7.7 \pm 7$ \\
\hline LFSA & $13.5 \pm 26.3$ & $10.3 \pm 10.2$ & $3.8 \pm 5$ & $15.7 \pm 15.5$ \\
\hline
\end{tabular}

BMI, Body-mass Index; BDI, Beck Depression Inventory; SKS, Sleep Quality Scale Specific; TFEQ, Three Factor Eating Questionnaire (with subscales): Snacking after placebo (PLC) and sucrose (CHO) for high-fat sweet (HFSW), low-fat sweet (LFSW), high-fat savory(HFSA) and low-fat savory (LFSA) snacks.

bi-allelic model as follows: $\mathrm{S} / \mathrm{S}, \mathrm{S} / \mathrm{Lg}$ and $\mathrm{Lg} / \mathrm{Lg}$ were classified as $\mathrm{S}^{\prime} / \mathrm{S}^{\prime}$ and $\mathrm{La} / \mathrm{La}$ as $\mathrm{L}^{\prime} / \mathrm{L}^{\prime}$.

\section{Salivary cortisol}

Saliva samples were obtained by using the Salivette sampling device (Sarstedt ${ }^{\circledR}$, Etten-Leur; the Netherlands). With this procedure, saliva was collected in small polyester swabs and stored $\left(-25^{\circ}\right.$ Celsius) immediately on collection (Figure 1$)$. Salivary free cortisol levels were determined in duplicate by a commercially available luminescence immunoassay (IBL, Hamburg, Germany). The lower limit of detection was $0.5 \mathrm{nmol} / \mathrm{L}$ and mean intra- and inter-assay coefficients of variation were less than $4 \%$ and $8 \%$, respectively.

\section{Statistical analyses}

Data were first examined for accuracy of data-entry, missing values and normal distributions. Hardy-Weinberg equilibrium was determined on the original 5-HTTLPR data-base $(N=771)$ using $\chi^{2}$ tests, revealing that the genotype frequencies of $\mathrm{S}^{\prime} / \mathrm{S}^{\prime}(N=158,21 \%), \mathrm{S} / \mathrm{L}(N=396,51 \%)$ and $\mathrm{L}^{\prime} / \mathrm{L}^{\prime}(N=217,28 \%)$ did not depart significantly from Hardy-Weinberg equilibrium $\left(\chi_{(1)}^{2}=0.87, p>0.351\right)$.

The main research questions were analyzed by means of repeated measures multivariate and univariate analyses of variance (MANOVA and ANOVA) by using the General Linear Model (GLM: SPSS 15.0 for Windows) with Genotype $\left(\mathrm{S}^{\prime} / \mathrm{S}^{\prime}\right.$ vs. $\left.\mathrm{L}^{\prime} / \mathrm{L}^{\prime}\right)$ and Diet (CHO vs. PLC) as between-subjects factor and Time $\left(\right.$ Baseline ${ }^{\mathrm{T} 1}$, after diet ${ }^{\mathrm{T} 2}$, before $^{\mathrm{T} 3}$ - and after ${ }^{\mathrm{T} 4}$ stress) or Stress (before ${ }^{\mathrm{T} 3}$ vs. after ${ }^{\mathrm{T} 4}$ stress) as within-subjects factors on the several dependent measures. For measuring effects on Liking for Foods (including four different food categories HFSW, HFSA, LFSW and LFSA) and Mood (including five different levels of the POMS), multivariate analyses of variance were performed. Strictly significant main or interaction effects revealed by these procedures were further examined by univariate tests. In the initial analyses, gender, body-mass index and depression (BDI) were included (separately) as covariates; although excluded from the final analyses due to their insignificance. Huynh-Feldt or Greenhouse-Geisser corrected $p$ values, their corresponding epsilons as well as the original, i.e. uncorrected, degrees of freedom are reported when the sphericity assumption was not met. All statistics were evaluated at a significance level of 5\% (two-tailed). Data are reported as mean $\pm \mathrm{SD}$ in the text and as mean \pm SEM in the figures.

\section{Results}

\section{Demographics}

Table 3 shows that the two genotypes $\left(\mathrm{S}^{\prime} / \mathrm{S}^{\prime}\right.$ and $\left.\mathrm{L}^{\prime} / \mathrm{L}^{\prime}\right)$ did not differ across a range of demographic measures and assessments including body mass index (BMI), depression, threefactor eating questionnaire (TFEQ) (including subscales) or pre-experiment sleep complaints (SKS-S).

\section{Cortisol}

Repeated measures analysis of variance with Genotype $\left(\mathrm{S}^{\prime} / \mathrm{S}^{\prime}\right.$ vs. $\left.\mathrm{L}^{\prime} / \mathrm{L}^{\prime}\right)$ and Diet (CHO vs. PLC) as between-subjects factor and Time Baseline $^{\mathrm{T} 1}$, after diet $^{\mathrm{T} 2}$, before ${ }^{\mathrm{T} 3}$ - and after $^{\mathrm{T} 4}$ stress) as within-subjects factors on salivary cortisol concentration only revealed a main effect of Time $[F(3,46)=34.31$; $p<0.001]$. Cortisol concentrations $(\mathrm{nmol} / \mathrm{L})$ declined from early morning baseline ( $\mathrm{t} 1=23.4 \pm 9.1)$ across dietary intake $(\mathrm{t} 2=22.4 \pm 11.3)$, pre-stress task performance $(\mathrm{t} 3=13.2 \pm 6.4)$ and stress exposure $(\mathrm{t} 4=12 \pm 6)$ regardless of dietary condition or genotype. There were no other main or interaction effects after separate post-hoc tests before- and after dietary intake or stress exposure. 


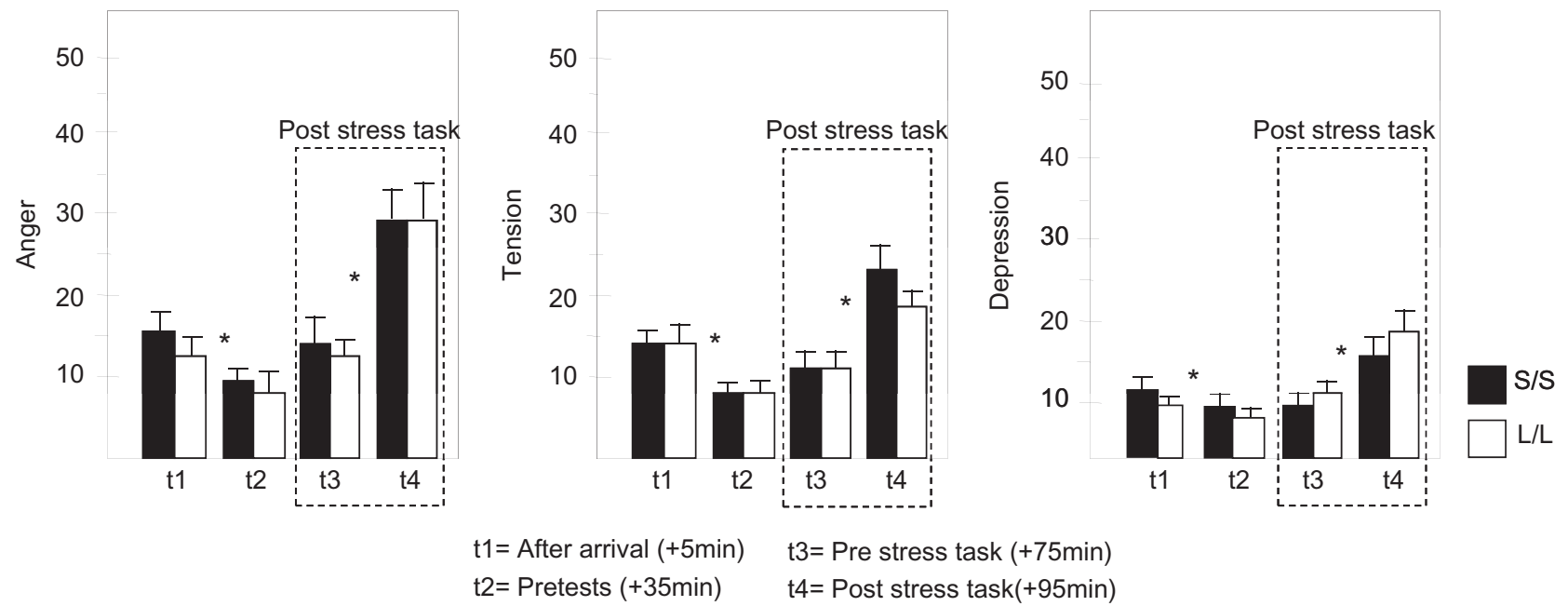

Figure 2. Changes in mood in $N=31 \mathrm{~S} / \mathrm{S}(\boldsymbol{\square})$ and $N=26 \mathrm{~L} / \mathrm{L}(\square)$ genotypes across arrival (t1), pre-test (t2), pre stress task exposure (t3) and post stress task exposure (t4). There was a significant increase $\left(^{*}\right)$ in post- compared to pre-stress task anger (MANOVA; $p<0.001$ ), tension (MANOVA; $p<0.001)$ and depression (MANOVA; $p<0.001)$ regardless of genotype or preload (data pooled across preload conditions).

\section{Mood}

A first overall repeated measures multivariate analysis of variance (MANOVA) with Genotype $\left(\mathrm{S}^{\prime} / \mathrm{S}^{\prime} \mathrm{vs}\right.$. $\left.\mathrm{L}^{\prime} / \mathrm{L}^{\prime}\right)$ and Diet (CHO vs. PLC) as between-subjects factor and Time (Baseline $^{\mathrm{T} 1}$, after $\operatorname{diet}^{\mathrm{T} 2}$, before ${ }^{\mathrm{T}}$ - and after $^{\mathrm{T} 4}$ stress) as within-subjects factors on the five subscales (measures) of the POMS only revealed an effect of Time $[F(15,39)=9.780$; $p<0.001]$. As shown in Figure 2, mood (anger, tension and depression) declined after arrival but increased from pre- to post-stress task exposure. Indeed, two separated repeated measures MANOVAs again only revealed a main effect for Time $\left(\right.$ Baseline ${ }^{\mathrm{T} 1}$ vs. pre-test/after $\operatorname{diet}^{\mathrm{T} 2}$ ) $[F(5,49)=13.880$; $p<0.001]$ and for Stress (pre-stress ${ }^{\mathrm{T} 3}$ vs. post-stress ${ }^{\mathrm{T} 4}$ ) $[F(5,49)=11.921 ; \quad p<0.001]$, indicating that participants became less angry $(p=0.003)$, less tense $(p<0.001)$ and less depressed ( $p=0.003$ ) $30 \mathrm{~min}$ after arrival, but then became more angry $(p<0.001)$, tense $(p<0.001)$ and depressed $(p=0.001)$ after stress task exposure. No effects of diet or genotype - or any other main or interaction effects were found.

\section{Appetite}

A first repeated measures ANOVA with Genotype $\left(\mathrm{S}^{\prime} / \mathrm{S}^{\prime}\right.$ vs. $\left.\mathrm{L}^{\prime} / \mathrm{L}^{\prime}\right)$ and Diet (CHO vs. PLC) as between-subjects factor and Stress (before ${ }^{\mathrm{T} 3}$ - and after $^{\mathrm{T} 4}$ stress) as within-subjects factors on "appetite to start a meal" only revealed a main effect of Stress $[F(1,53)=20.342 ; p<0.001]$. As indicated in Figure 3, appetite to start a meal increased between before stress task exposure to after stress task exposure.

A second repeated measures ANOVA with Genotype $\left(\mathrm{S}^{\prime} / \mathrm{S}^{\prime}\right.$ vs. $\left.\mathrm{L}^{\prime} / \mathrm{L}^{\prime}\right)$ and Diet (CHO vs. PLC) as between-subjects factor and Type-of-snack (sweet vs. savory) and Stress (before ${ }^{\mathrm{T} 3}$ - and after $^{\mathrm{T} 4}$ stress) as within-subjects factors on "appetite for a snack' only revealed a main effect of Type-of-snack $[F(1,53)=9.0 ; \quad p=0.004]$ and a main effect of Stress $[F(1,53)=28.56 ; p<0.001]$; indicating that appetite for a sweet snack was greater than appetite for a savory snack and that stress task exposure increased general appetite for a
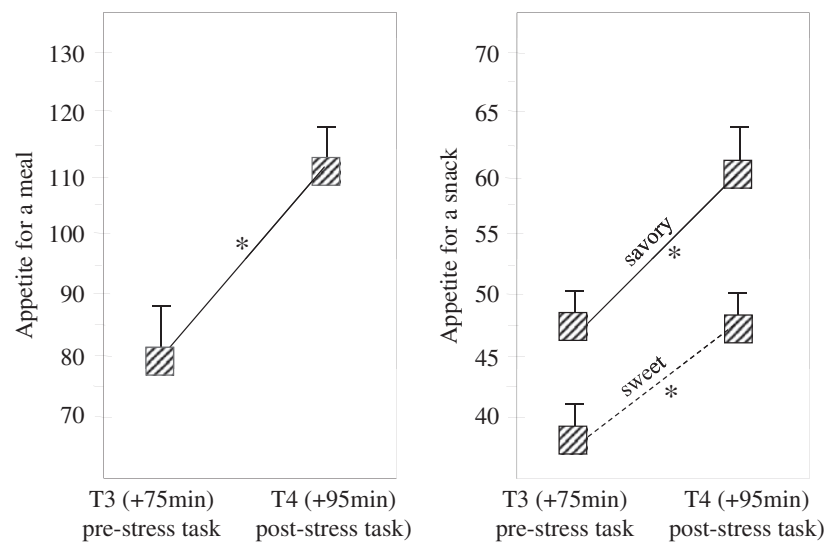

Figure 3. Acute stress task exposure significantly (*) increased subjective sensation of appetite for a meal (ANOVA; $p<0.001)$ as well as appetite for a savory (ANOVA; $p<0.001$ ) and sweet snack (ANOVA; $p=0.002)$ regardless of genotype or preload condition $(N=57$; data pooled across genotype and preload conditions). Data are mean \pm S.E.M. There was a greater subjective sensation of appetite for a savory snack than for a sweet snack (ANOVA; $p=0.004$ ) regardless of stress task exposure.

snack; for a sweet snack $(p=0.002)$ as well as for a savory snack $(p<0.001)$ (Figure 3). No effects of diet or genotype or any other main or interaction effects - were found.

\section{Liking for foods}

Repeated measures MANOVA with Genotype $\left(\mathrm{S}^{\prime} / \mathrm{S}^{\prime}\right.$ vs. $\left.\mathrm{L}^{\prime} / \mathrm{L}^{\prime}\right)$ and Diet (CHO vs. PLC) as between-subjects factor and Stress (before $^{\mathrm{T} 3}$ - and after ${ }^{\mathrm{T} 4}$ stress) as within-subjects factors on liking for foods for the four food categories HFSW, HFSA, LFSW and LFSA only revealed a main effect of Stress $[F(4,50)=12.888 ; p<0.001]$ that appeared to originate from increases in liking for high-fat foods including HFSW $(p<0.001)$ and HFSA $(p<0.001)$ but not for the low-fat foods ( $p>0.68$ and $p>0.25$ respectively). Indeed, a second repeated measures analyses also including Food Type (HFSW, HFSA, LFSW, LFSA) as an additional within-subjects factor again revealed a main effect of Stress $[F(1,53)=28.305$; 
Likingfor

High fat Food
Likingfor

Low fat Food
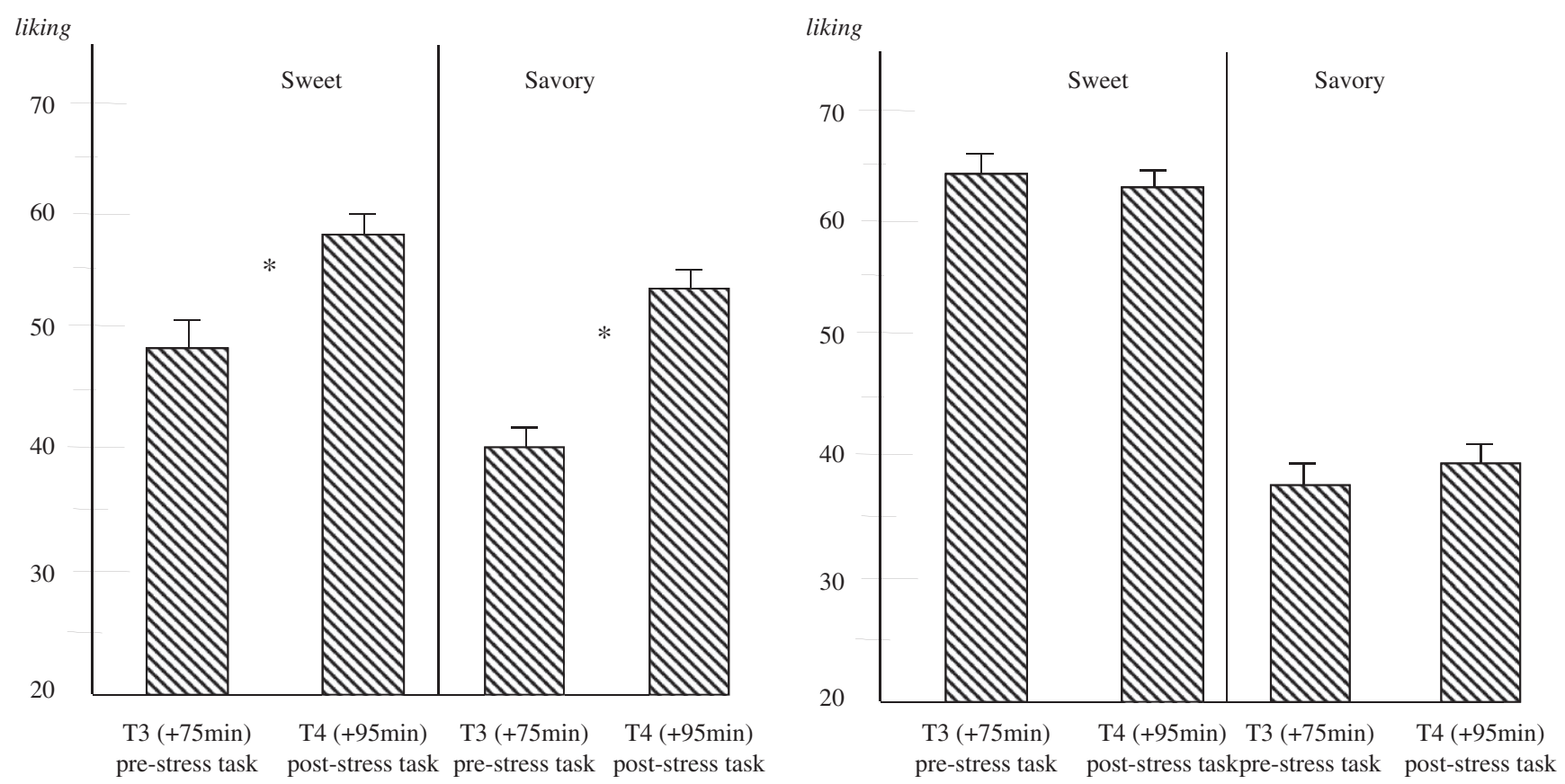

Figure 4. Effects for acute stress task exposure on changes in liking for computerized food cues (pictures) were only found to be significant (*) for high fat sweet food cues (MANOVA; $p<0.001$ ) and savory food cues (MANOVA; $p<0.001$ ) but not for low fat food cues $(N=57$ ). Data are mean \pm S.E.M. High-fat sweet (HFSW) as well as high-fat savory (HFSA) food pictures increased subjective sensation of appetite for meals and snacks regardless of genotype or preload condition (data pooled for meals and snacks across genotype and preload conditions).

$p<0.001]$ and an interaction of Stress $\times$ Food-type $[F(3,51)=11.156 ; p<0.001]$. As shown in Figure 4, stress task exposure only increases liking for HFSW $(p<0.001)$ and HFSA $(p<0.001)$ but not for low-fat foods (LFSW $p>0.65$; LFSA $p>0.21)$. No effects were found including genotype or diet.

\section{Food intake}

A first overall repeated measures ANOVA with Genotype $\left(\mathrm{S}^{\prime} / \mathrm{S}^{\prime}\right.$ vs. $\left.\mathrm{L}^{\prime} / \mathrm{L}^{\prime}\right)$ and Diet $\mathrm{CHO}$ vs. PLC) as between-subjects factor and Food Type (HFSW, HFSA, LFSW, LFSA) as withinsubjects factor on food snacking revealed a main effect of Food-Type $[F(3,51)=15.837 ; p<0.001]$ and an interaction of Gene $\times$ Diet $\times$ Food-Type $[F(3,51)=3.215 ; p=0.03]$. As indicated in Figure 5, snacking was greater for total High-fat foods $(64 \pm 29 \mathrm{~g})$ than for total low-fat foods $(10.5 \pm 15 \mathrm{~g})[p<0.001]$ and only for high-fat foods there was an increased preference for consuming sweet $(44 \pm 36 \mathrm{~g})$ compared to savory $(20 \pm 22 \mathrm{~g})$ snacks $[p<0.001]$. Moreover, this increased snacking for high-fat sweet foods significantly differed in $S^{\prime} / S^{\prime}$ compared to $L^{\prime} / L^{\prime}$ depending on dietary (preload) intake. Analysis for the hypothesized changes regarding sweet from savory high-fat foods (HFSA vs. HFSW) indeed revealed an interaction of Genotype $\times$ Diet $\times$ Food-Type for high-fat food $[F(1,53)=9.340 ; p=0.004]$. This was not found for Low-fat (LFSA vs. LFSW) foods $(p>0.3)$. As indicated in Figure 6, the increased preference for HFSW over HFSA food intake is significantly greater in $S^{\prime} / S^{\prime}$ than in $L^{\prime} / L^{\prime}$ genotypes and only in $\mathrm{S}^{\prime} / \mathrm{S}^{\prime} \mathrm{HFSW}$ is snacking reduced after $\mathrm{CHO}$ intake compared to PLC intake $(p=0.027)$.

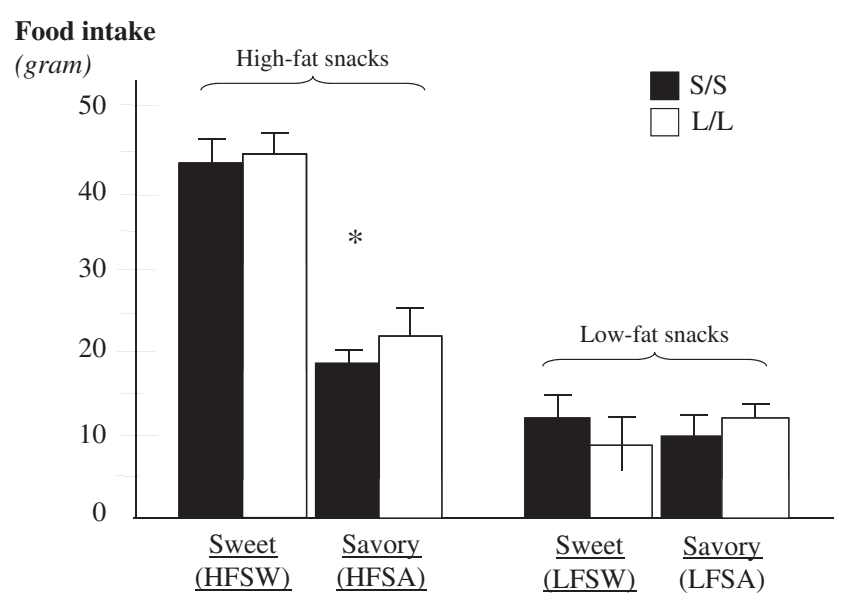

Figure 5. Food intake after completion of the stress task was greater for high-fat snacks than for low-fat snacks (MANOVA; $p<0.001$ ) and only for high-fat snacks there was an increased preference to consuming sweet (HFSW) compared to savory HFSA) snacks (*; ANOVA; $p<0.001$ ). Data are mean \pm S.E.M.

\section{Discussion}

The aim of the present study was to investigate whether a sucrose-containing preload would reduce negative effect of stress task exposure and, hence, negative mood on increasing appetite and craving for foods and therefore reduce high-fat sweet food intake compared to high-fat savory food intake based on the 5-HTTLPR genotype. Although stress task exposure increased negative mood and appetite and craving for high-fat food regardless of preload condition or 5-HTTLPR, the subsequent increased intake of high-fat 
Figure 6. The increased intake of high-fat sweet (HFSW) snacks over high-fat savory (HFSA) snacks was significantly greater in $N=31 \mathrm{~S} / \mathrm{S}(\mathbf{\square})$ than in $N=26 \mathrm{~L} / \mathrm{L}(\square)$ genotypes (ANOVA $p=0.03$ ) and only in $\mathrm{S} / \mathrm{S}$ participants was prevented by $\mathrm{CHO}$ compared to PLC intake (ANOVA $p=0.027$ ).

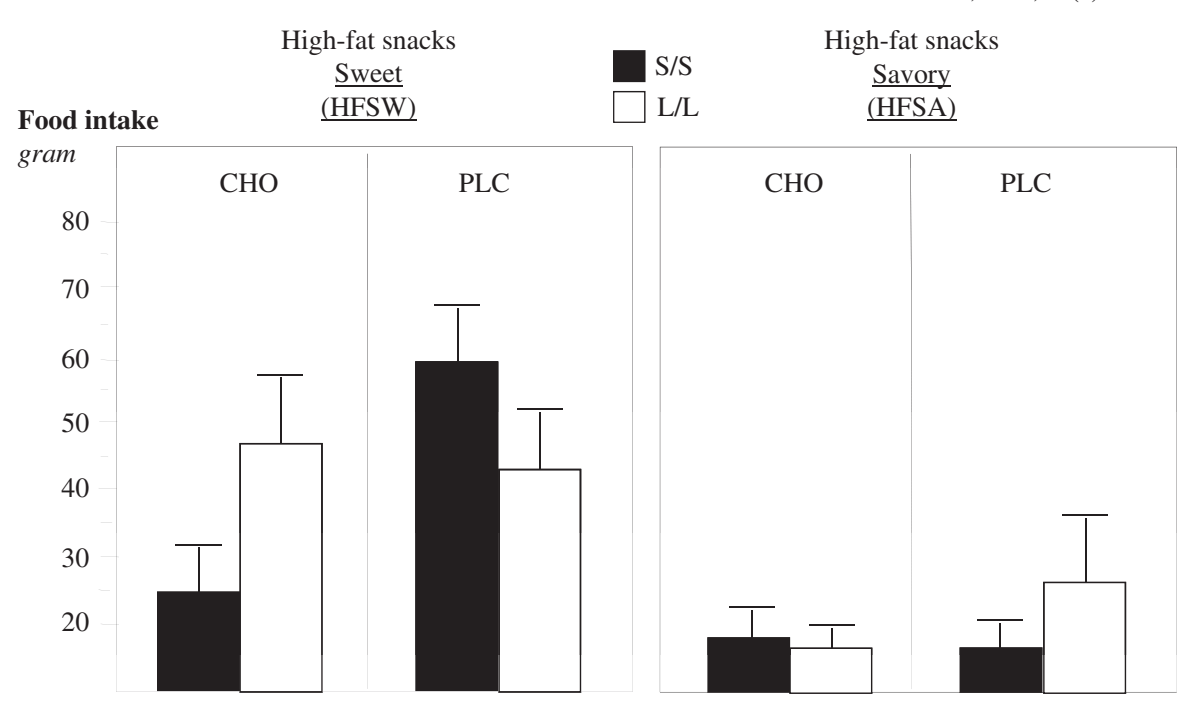

sweet food was significantly greater in $S^{\prime} / S^{\prime}$ than in $L^{\prime} / L^{\prime}$ individuals, and this was significantly reduced by a sucrose preload in only $\mathrm{S}^{\prime} / \mathrm{S}^{\prime}$ individuals.

\section{Acute stress}

Although cortisol responses were not observed, the MPA stress task significantly increased feelings of anger, tension and depression. However, contrary to expectations, this negative affective response was not mediated by 5-HTTLPR or preload condition. Regarding cortisol, previous acute stress studies report mixed results, including stress-induced cortisol responses in only $\mathrm{S} / \mathrm{S}$ individuals or stress cortisol responses that were greater in $\mathrm{S} / \mathrm{S}$ subjects compared to $\mathrm{L} / \mathrm{L}$ subjects (Gotlib et al., 2008; Mueller et al., 2010; Way \& Taylor, 2010), greater in L-allele subjects compared to S-allele subjects (Mueller et al., 2011) or no 5-HTTLPR-dependent changes in stress-induced cortisol responses at all (Firk, 2009; Markus \& Firk, 2009; Markus et al., 2012; Verschoor \& Markus, 2011a,b, 2012; Wust et al., 2009). The absence of cortisol responses in the current study most likely indicates that this stress task was not severe enough to activate a physiological hypothalamo-pituitary adrenal cortisol response. However, in previous studies, the same task did cause cortisol stress responses often accompanying comparable mood changes as found in the current study (Markus et al., 1998; Merens et al., 2005; Verschoor et al., 2010). Considering that pre-stress task cortisol measures in the current design were taken $40 \mathrm{~min}$ before onset of the stress task, this time point might have been too early to detect the cortisol responses as cortisol concentrations could have further declined below post-stress task levels at the time of stress task onset.

Of the studies that explored 5-HTTLPR differences in affective stress reactivity (Markus \& De Raedt, 2011; Markus \& Firk, 2009; Verschoor \& Markus, 2011a,b; Way \& Taylor, 2010), only a few revealed that a more pronounced stress task induced negative mood in S/S compared to $\mathrm{L} / \mathrm{L}$ participants (Markus \& De Raedt, 2011; Verschoor \& Markus, 2011). By contrast, negative mood and depression symptoms have consistently been found to be a function of increased past stressful life events in individuals with the S-allele 5-HTTLPR genotype (Karg et al., 2011). Evidently, compared to a series of natural daily hassles, exposure to a brief mild laboratory stress task does not always induce an adequate response to indicate 5-HTTLPR interference. Interestingly, 5-HTTLPR interference on acute affective stress task responses might become more vivid when also controlling for the frequency of past stress experiences (Alexander et al., 2009; Verschoor \& Markus, 2011b) and/or trait neuroticism (Verschoor \& Markus, 2011b).

\section{Appetite and food craving}

The subjective sensation of appetite was significantly increased after the stress task exposure compared to before the stress task exposure. In addition, the computerized food craving task, including high-fat and low-fat sweet and savory food pictures, revealed a stronger increase in the preferences for high fat food cues after stress task exposure. Although these findings partly support previous reports of stress related changes in sensations of appetite and food preferences in healthy subjects (Newman et al., 2008; Verschoor et al., 2010) and in subjects with a vulnerability to increase their food intake due to negative external events (Newman et al., 2008) or overweight subjects (Lemmens et al., 2011), craving for food was not stronger for the high-fat sweet food cues, did not depend on 5-HTTLPR and was not influenced by preload condition. However, even though subjective sensations of appetite for food words or pictures were influenced by stress task exposure, a 5-HTTLPR effect might only be induced when the more appealing impact of actual palatable food that can be consumed is presented. Indeed, the current findings revealed a 5-HTTLPR-dependent preload effect on actual food intake.

\section{Real food intake}

As expected, the increase in negative mood after stress task exposure primarily increases high-fat food intake compared to low-fat food intake, particularly when these high-fat foods were sweet instead of savory. Interestingly, this apparent negative mood induced increase in HFSW food intake was more pronounced in $\mathrm{S} / \mathrm{S}$ - compared with L/L-allele participants, and it was only reduced by the sucrose preload in $\mathrm{S} / \mathrm{S}$ 
participants. It is important to note, however, that the current experiment did not include baseline food intake measures. It may thus still be possible that this increased snacking on high-fat sweet foods also represents an increase in appetite over the course of the experimentHowever, because the stress task caused negative affective responses that were also found in previous studies to increase HFSW food intake (Epel et al., 2001; Greeno \& Wing, 1994; Oliver et al., 2000; Rutters et al., 2009; Wardle et al., 2000), it is likely that the increases in HFSW food intake in the current study were caused by the mild negative mood experience. Furthermore, the increase in HFSW food has been shown to be greater in $S^{\prime} / S^{\prime}$ subjects who (1) are found to be stress vulnerable (Caspi et al., 2003; Gotlib et al., 2008; Karg et al., 2011), (2) have increased risk for weight gain and eating-related disturbances, such as obesity (Erritzoe et al., 2010; Sookoian et al., 2007b, 2008), and (3) are found to report more eating-related disturbances due to past stressful events or negative mood (Akkerman et al., 2012; Stoltenberg et al., 2012; Van Strien et al., 2010). The current study is the first to reveal that individuals with S/S-allele 5-HTTLPR genotypes might have an increased risk for HFSW food snacking after negative mood experiences and that these individuals may be more vulnerable to the satiation effects of a sucrose preload.

\section{How does sucrose reduce HFSW food intake in S/S participants?}

Sugar (sucrose) consumption is known to reduce postprandial food intake probably due to increases in blood glucose levels and increased satiation signals from hypothalamic brain areas (Leibowitz \& Alexander, 1998; Leibowitz et al., 1989). In the present study, the preload satiety effects were the strongest for HFSW food intake as a function of 5-HTTLPR, even though snacking in the current design was only allowed for $15 \mathrm{~min}$ in a non-natural (laboratory) setting.

One might in first instance argue that the sucrose preload reduced snacking behavior as compared to the PLC because of its higher caloric value. Although sweetness was controlled for the PLC, this was not the case for differences in calories. This however does not explain why the sucrose preload was only found to reduce HFSW intake. It may be possible that this exclusive effect of sucrose preload on HFSW snacking is caused by a preference for HFSW over HFSA. Yet, participants in the current study nevertheless did consume HFSA snacks without showing any intent of effect in the same direction as found for HFSW. Similarly important is the question of why this sucrose effect on snacking is then particularly present in S/S carriers. This finding may fit with the "bright side-plasticity hypothesis"' (Belsky et al., 2009) allowing $\mathrm{S} / \mathrm{S}$ carriers to become even better adaptors to environmental changes in the absence of stress; increasing food intake under a threat of caloric shortage (PLC) and vice versa after caloric (sucrose) load. However, this may be expected also for the higher caloric HFSA snacks.

An alternative explanation that better fits with the current findings is that the sucrose preload may have caused slightly more profound effects on brain 5-HT synthesis and release in S/ $\mathrm{S}$ genotypes due to an enhanced brain 5-HT sensitization and brain 5-HT vulnerability to compensate for the lower 5-HT expression (David et al., 2005; Jans et al., 2007; Moore, 2000). A comparable sugar preload has already been suggested to slightly increase brain TRP and 5-HT levels by raising the plasma TRP influx into the brain (Markus, 2008). Dietary manipulations of brain TRP and 5-HT levels are sometimes found to have a greater impact on 5-HT-related stress or affective behavior in S-allele carriers (Neumeister et al., 2002, 2006). Therefore, a sugar-containing preload might be expected to reduce HFSW compared to HFSA food intake particularly in S/S individuals, causing enhanced synthesis and release of hypothalamic 5-HT in areas that selectively control food intake (Leibowitz \& Alexander, 1998; Leibowitz et al., 1989). Consistent with this suggestion, S/S individuals consumed more HFSW foods than L/L individuals after PLC, which supports the assumption of reduced hypothalamic 5-HT function in S/S individuals, while they consumed less HFSW foods after a sucrose pre-load, which supports the assumption of increased hypothalamic 5-HT function. The increased intake of HFSW food in S/S-allele genotypes following completion of the stress task also supports the assumption that stress exposure may further reduce brain 5-HT levels in chronically stressed or 5-HT-vulnerable individual (Markus, 2008).

\section{Limitation}

A possible limitation of the current study may be the oversampling of female $(N=40)$ compared to male $(N=17)$ participants, which makes it not possible to decide whether gender might have influenced the results. Although the inclusion of Gender as a covariate (or as a full factor) in the current analyses did not change the initial findings; gender differences in liking for sweet versus savory/salty foods may nevertheless be a moderating factor for (differences in) stressinduced food preferences in much larger database studies. The design of the current study (small gender group sizes) does not allow answering such questions; this needs to be addressed in future studies.

\section{Conclusion}

The current findings reveal that increased intake of high-fat sweet food after the completion of an acute stress task that causes negative mood was greater in S/S-allele 5-HTTLPR participants than in L/L-allele 5-HTTLPR participants. This effect was prevented by a sucrose-containing preload in $\mathrm{S} / \mathrm{S}$ participants only. Although alternative explanations are possible, it is suggested that these effects may be caused by a more enhanced brain (hypothalamic) 5-HT sensitization in S/S participants, which would make them more susceptible to eating-related disturbances and furthermore to the negative effects of stress exposure on weight gain.

\section{Declaration of interest}

All authors ensure the integrity of the work and none of them has any direct or indirect financial or personal interests, or conflicts of interest, to the subject matter of the manuscript.

This study was supported by Knowledge-center Sugar and Nutrition (Baarn, The Netherlands) in supplying the sucrose and PLC sources, but had no part whatsoever neither in the 
design and conduct of the study nor in the analyses, interpretation and publication of the results.

\section{References}

Akkerman K, Kaasik K, Kive E, Al E. (2012). The impact of adverse life events and the serotonin transporter gene promoter polymorphism on the development of eating disorder symptoms. J Psychiatr Res 46: 39-43.

Alexander N, Kuepper Y, Schmitz A, Osinsky R, Kozyra E, Hennig J. (2009). Gene-environment interactions predict cortisol responses after acute stress: implications for the etiology of depression. Psychoneuroendocrinology 34:1294-303.

Belsky J, Pluess M. (2009). Beyond diathesis stress: differential susceptibility to environmental influences. Psychol Bull 135:885-908.

Bennett DA, Cooper CL. (1999). Eating disturbance as a manifestation of the stress process; a review of the literature. Stress Med 15:167-82.

Brewerton TD. (1995). Towards a unified theory of serotonin dysregulation in eating and related disorders. Psychoneuroendocrinology 20:561-90.

Bruce KR, Steiger H, Young SN, Kin NM, Israel M, Levesque M. (2009). Impact of acute tryptophan depletion on mood and eatingrelated urges in bulimic and nonbulimic women. J Psychiatry Neurosci 34:376-82.

Brunstrom JM. (2007). Associative learning and the control of human dietary behavior. Appetite 49:268-71.

Calati R, De Ronchi D, Bellini M, Serretti A. (2010). The 5-HTTLPR polymorphism and eating disorders: a meta analysis. Int $\mathrm{J}$ Eat disord 44:191-9.

Caspi A, Hariri AR, Holmes A, Uher R, Moffitt TE. (2010). Genetic sensitivity to the environment: the case of the serotonin transporter gene and its implications for studying complex diseases and traits. Am J Psychiatry 167:509-27.

Caspi A, Sugden K, Moffitt TE, Taylor A, Craig IW, Harrington H, Mcclay J, et al. (2003). Influence of life stress on depression: moderation by a polymorphism in the 5-HTT gene. Science 301: 386-9.

David SP, Murthy NV, Rabiner EA, Munafo MR, Johnstone EC, Jacob R, Walton RT, Grasby PM. (2005). A functional genetic variation of the serotonin $(5-\mathrm{HT})$ transporter affects 5-HT1A receptor binding in humans. J Neurosci 25:2586-90.

Epel E, Lapidus R, Mcewen B, Brownell K. (2001). Stress may add bite to appetite in women: a laboratory study of stress-induced cortisol and eating behavior. Psychoneuroendocrinology 26:37-49.

Erritzoe D, Frokjaer VG, Haahr MT, Kalbitzer J, Svarer C, Holst KK, Hansen DL, et al. (2010). Cerebral serotonin transporter binding is inversely related to body mass index. Neuroimage 52:284-9.

Fernstrom JD, Wurtman RJ. (1971). Brain serotonin content: physiological dependence on plasma tryptophan levels. Science 173:149-52.

Finlayson G, King N, Blundell JE. (2007). Is it possible to dissociate 'liking' and 'wanting' for foods in humans? Physiol Behav 90:36-42.

Firk C, Markus Cr. (2009). Differential effects of 5-HTTLPR genotypes on mood, memory and attention bias following acute tryptophan depletion and stress exposure. Psychopharmacology (Berl) 203: 805-18.

Gibson EL, Carnell S, Wardle J. (2006). Learnt satiation in effects of disguised preloads on lunch intake and appetite in preschool children. Appetite 47:Abstracts 280-1.

Glatz K, Mossner R, Heils A, Lesch KP. (2003). Glucocorticoidregulated human serotonin transporter (5-HTT) expression is modulated by the 5-HTT gene-promotor-linked polymorphic region. J Neurochem 86:1072-8.

Gotlib IH, Joormann J, Minor KL, Hallmayer J. (2008). HPA axis reactivity: a mechanism underlying the associations among 5-HTTLPR, stress, and depression. Biol Psychiatry 63:847-51.

Greeno CG, Wing RR. (1994). Stress-induced eating. Psychol Bull 115: 444-64.

Heatherton TF, Herman CP, Polivy J. (1991). Effects of physical threat and ego threat on eating behavior. J Pers Soc Psychol 60:138-43.

Heils A, Teufel A, Petri S, Stober G, Riederer P, Bengel D, Lesch KP. (1996). Allelic variation of human serotonin transporter gene expression. J Neurochem 66:2621-4.

Jans LA, Riedel WJ, Markus CR, Blokland A. (2007). Serotonergic vulnerability and depression: assumptions, experimental evidence and implications. Mol Psychiatry 12:522-43.
Karg K, Burmeister M, Shedden K, Sen S. (2011). The serotonin transporter promoter variant (5-HTTLPR), stress, and depression meta-analysis revisited: evidence of genetic moderation. Arch Gen Psychiatry 68:444-54.

Kaye W. (2008). Neurobiology of anorexia and bulimia nervosa. Physiol Behav 94:121-35.

Leibowitz SF, Alexander JT. (1998). Hypothalamic serotonin in control of eating behavior, meal size, and body weight. Biol Psychiatry 44: 851-64.

Leibowitz SF, Weiss GF, Walsh UA, Viswanath D. (1989). Medial hypothalamic serotonin: role in circadian patterns of feeding and macronutrient selection. Brain Res 27:132-40.

Lemmens SG, Rutters F, Born JM, Westerterp-Plantenga MS. (2011). Stress augments food 'wanting' and energy intake in visceral overweight subjects in the absence of hunger. Physiol Behav 103: $157-63$.

Lesch KP, Bengel D, Heils A, Sabol SZ, Greenberg BD, Petri S, Benjamin J, et al. (1996). Association of anxiety-related traits with a polymorphism in the serotonin transporter gene regulatory region. Science 274:1527-31.

Lucki I. (1998). The spectrum of behaviors influenced by serotonin. Biol Psychiatry 44:151-62.

Markus CR, De Raedt R. (2011). Differential effects of 5-HTTLPR genotypes on inhibition of negative emotional information following acute stress exposure and tryptophan challenge. Neuropsychopharmacology 36:819-26.

Markus CR, Firk C. (2009). Differential effects of tri-allelic 5-HTTLPR polymorphisms in healthy subjects on mood and stress performance after tryptophan challenge. Neuropsychopharmacology 34:2667-74.

Markus CR, Panhuysen G, Jonkman LM, Bachman M. (1999). Carbohydrate intake improves cognitive performance of stress-prone individuals under controllable laboratory stress. Br J Nutr 82:457-67.

Markus CR, Panhuysen G, Tuiten A, Koppeschaar H, Fekkes D, Peters ML. (1998). Does carbohydrate-rich, protein-poor food prevent a deterioration of mood and cognitive performance of stress-prone subjects when subjected to a stressful task? Appetite 31:49-65.

Markus CR, Verschoor E, Smeets T. (2012). Differential effect of the 5-HTT gene-linked polymorphic region on emotional eating during stress exposure following tryptophan challenge. J Nutr Biochem 23: $410-16$.

Markus CR. (2008). Dietary amino acids and brain 5-HT function; implications for stress and stress-related affective changes. Neuromolecular Med 10:247-58.

Merens W, Booij L, Markus R, Zitman FG, Onkenhout W, Van Der Does AJ. (2005). The effects of a diet enriched with alpha-lactalbumin on mood and cortisol response in unmedicated recovered depressed subjects and controls. Br J Nutr 94:415-22.

Mitchell SL, Epstein LH. (1996). Changes in taste and satiety in dietaryrestrained women following stress. Physiol Behav 60(2):495-9.

Moore P, Landolt Hp, Seifritz E, Clark C, Bhatti T, Kelsoe J, Rapaport M, Gillin JC. (2000). Clinical and physiological consequences of rapid tryptophan depletion. Neuropsychopharmacology 23:601-22.

Mueller A, Armbruster D, Moser DA, Canli T, Lesch KP, Brocke B, Kirschbaum C. (2011). Interaction of serotonin transporter genelinked polymorphic region and stressful life events predicts cortisol stress response. Neuropsychopharmacology 36:1332-9.

Mueller A, Brocke B, Fries E, Lesch KP, Kirschbaum C. (2010). The role of the serotonin transporter polymorphism for the endocrine stress response in newborns. Psychoneuroendocrinology 35:289-96.

Neumeister A, Hu XZ, Luckenbaugh DA, Schwarz M, Nugent AC, Bonne O, Herscovitch P, et al. (2006). Differential effects of 5-HTTLPR genotypes on the behavioral and neural responses to tryptophan depletion in patients with major depression and controls. Arch Gen Psychiatry 63:978-86.

Neumeister A, Konstantinidis A, Stastny J, Schwarz MJ, Vitouch O, Willeit M, Praschak-Rieder N, et al. (2002). Association between serotonin transporter gene promoter polymorphism (5HTTLPR) and behavioral responses to tryptophan depletion in healthy women with and without family history of depression. Arch Gen Psychiatry 59: 613-20.

Newman E, O'connor DB, Conner M. (2008). Attentional biases for food stimuli in external eaters: possible mechanism for stress-induced eating? Appetite 51:339-42.

Oliver G, Wardle J, Gibson EL. (2000). Stress and food choice: a laboratory study. Psychosom Med 62:853-65. 
Racine SE, Culbert KM, Larson CL, Klump KL. (2009). The possible influence of impulsivity and dietary restraint on associations between serotonin genes and binge eating. J Psychiatr Res 43:1278-86.

Rutters F, Nieuwenhuizen AG, Lemmens SG, Born JM, WesterterpPlantenga MS. (2009). Acute stress-related changes in eating in the absence of hunger. Obesity (Silver Spring) 17:72-7.

Simansky KJ. (1996). Serotonergic control of the organization of feeding and satiety. Behav Brain Res 73:37-42.

Sookoian S, Gemma C, Garcia SI, Gianotti TF, Dieuzeide G, Roussos A, Tonietti M, et al. (2007a). Short allele of serotonin transporter gene promoter is a risk factor for obesity in adolescents. Obesity (Silver Spring) 15:271-6.

Sookoian S, Gemma C, Gianotti TF, Burgueno A, Alvarez A, Gonzalez CD, Pirola CJ. (2007b). Serotonin and serotonin transporter gene variant in rotating shift workers. Sleep 30:1049-53.

Sookoian S, Gianotti TF, Gemma C, Al E. (2008). Contribution of the functional 5-HTTLPR variant of the SLC6A4 gene to obesity risk in male adults. Obesity 16:488-91.

Stallone D, Nicolaidis S. (1989). Increased food intake and carbohydrate preference in the rat following treatment with the serotonin antagonist metergoline. Neurosci Lett 102:319-24.

Stoltenberg SF, Anderson C, Nag P, Anagnopoulos C. (2012). Association between the serotonin transporter triallelic genotype and eating problems is moderated by the experience of childhood trauma in women. Int J Eat Disord 45:492-500.

Uher RMP. (2008). The moderation by the serotonin transporter gene of environmental adversity in the aetiology of mental illness: review and methodological analysis. Mol Psychiatry 13:131-46.

Van Strien T, Engels RC, Van Leeuwe J, Snoek HM. (2005). The Stice model of overeating: tests in clinical and non-clinical samples. Appetite 45:205-13.

Van Strien T, Van Der Zwaluw CS, Engels RC. (2010). Emotional eating in adolescents: a gene (SLC6A4/5-HTT) - depressive feelings interaction analysis. J Psychiatr Res 44(15):1035-42.

Verschoor E, Finlayson G, Blundell J, Markus CR, King NA. (2010). Effects of an acute alpha-lactalbumin manipulation on mood and food hedonics in high- and low-trait anxiety individuals. Br J Nutr 104: 595-602.
Verschoor E, Markus CR. (2011a). Affective and neuroendocrine stress reactivity to an academic examination: influence of the 5-HTTLPR genotype and trait neuroticism. Biol Psychol 87:439-49.

Verschoor E, Markus CR. (2011b). Effects of acute psychosocial stress exposure on endocrine and affective reactivity in college students differing in the 5-HTTLPR genotype and trait neuroticism. Stress 14: 407-19.

Verschoor E, Markus CR. (2012). Physiological and affective reactivity to a $35 \% \mathrm{CO}(2)$ inhalation challenge in individuals differing in the 5-HTTLPR genotype and trait neuroticism. Eur Neuropsychopharmacol 22:546-54.

Wald FD. M, Mellenbergh GJ. (1990). De verkorte versie van de Nederlandse vertaling van de profile of mood states (POMS). Ned Tijdschr Psychol 45:86-90.

Walderhaug E, Magnusson A, Neumeister A, Lappalainen J, Lunde H, Refsum H, Landro NI. (2007). Interactive effects of sex and 5-HTTLPR on mood and impulsivity during tryptophan depletion in healthy people. Biol Psychiatry 15:593-9.

Wardle J, Steptoe A, Oliver G, Lipsey Z. (2000). Stress, dietary restraint and food intake. J Psychosom Res 48:195-202.

Way BM, Taylor SE. (2010). The serotonin transporter promoter polymorphism is associated with cortisol response to psychosocial stress. Biol Psychiatry 67:487-92.

Wurtman RJ, Wurtman JJ, Regan MM, Mcdermott JM, Tsay RH, Breu JJ. (2003). Effects of normal meals rich in carbohydrates or proteins on plasma tryptophan and tyrosine ratios. Am J Clin Nutr 77: 128-32.

Wust S, Kumstra R, Treutlein J, Frank J, Entringer S, Schulze TG, Rietschel M. (2009). Sex-specific association between the 5-HTT gene-linked polymorphic region and basal cortisol secretion. Psychoneuroendocrinology 34:972-82.

Zalsman G, Huang YY, Oquendo MA, Burke AK, Hu XZ, Brent DA, Ellis SP, et al. (2006). Association of a triallelic serotonin transporter gene promoter region (5-HTTLPR) polymorphism with stressful life events and severity of depression. Am J Psychiatry 163:1588-93.

Zellner DA, Loaiza S, Gonzales Z. (2006). Food selection changes under stress. Physiol Behav 87:789-93. 